\title{
Recitation and Tajweed Improvement Strategies within Tafilah Schools' Students in the Viewpoint of Islamic Education Teachers
}

\author{
Dr Abdullah Ali Al-Jazi \\ Assistant professor, Faculty of educational sciences \\ Department of curriculum and teaching methods \\ Tafila Technical University \\ E-mail: aaljazi@ttu.edu.jo
}

Received: August 1, 2017 Accepted: Sep. 18, $2017 \quad$ Published: November 1, 2017

doi:10.5296/jse.v7i4.12091 URL: https://doi.org/10.5296/jse.v7i4.12091

\begin{abstract}
This study aims at exploring Qur'anic recitation and tajweed improvement strategies within school students in Tafilah governorate, Jordan, in the viewpoint of Islamic Education teachers. To achieve this aim a data collection instrument was established: that is a questionnaire distributed to the Islamic Education teachers after validating psychometric characteristics of it. Data analysis results revealed existence of a number of strategies within the sample students, subject of the study. The study also revealed that there was no statistically significant difference in the Qur'anic recitation and tajweed improvement strategies that can be attributed to variables of: the gender or teaching experience.
\end{abstract}

Keywords: Recitation, Tajweed, Tafilah Schools, Islamic Education Teachers 


\section{Introduction}

Reciting and tajweeding the Qur'an correctly the way it was revealed to our messenger Muhammad is firstly a divine commandment. Allah says: “..., and with recitation, recite the Qur'an” (Al Muzzammil: 4). Furthermore, a lot of the Prophetic Tradition (Hadeeth: sayings) assert the importance and virtue of reciting Allah's Book and words correctly and ideally. Showing the highly-ranked position of the Qur'anic verses reader as learner or teacher, the Prophet says: "The best of you is that who learns the Qur'an and teaches It." (Al Bukhari, Virtues of the Qur'an: no 4739).

He also says: “A Qur'an's reader who has learnt it (by heart) is with the company of the noble and pious; while that who frequently endeavours to read the Qur'an as it is hard to him are twice rewarded" (Ibid, no 4937). 'Reciting' the Holy Qur'an denotes 'reading' it: as one meaning of 'recite' is 'to read and comprehensively follow'. It could also mean 'to consider, recall, view and learn lessons' (Ramadan, 1425).

Tajweed, on the other hand, linguistically means 'improved recitation'; and idiomatically (in terms of the phonetic domain of this science) "articulating the (verses') sounds correctly as phonetically prescribed observing all pronunciation features of sounding these" (Jum'ah, 2004). Al Jamal (2004: 43) defines Tajweed as "a science that studies the Qur'anic verses and lexemes in terms of phonetic articulation of them observing all pronunciation characteristics when uttering them": Pronunciation prescriptions denote original phonetic characteristics of the sounds and morphological ones (dependent on their distribution) like the dark ' 1 ' and the soft ' 1 '.

\subsection{The virtue of reciting and tajweeding the Qur'an}

Reciting and tajweeding the Qur'anic verses are in Islam one of the best deeds through which a Muslim asks approach to Allah (Most High). Allah says: "recite from the Koran as much as is easy (for you)" (Al Muzzammil: 20). In line with this, the Prophe contended that a Muslim is promoted higher in the paradise, and his rank rises compatibly with what he/she has learnt (by heart) of Allah's Book. The Messenger says “The Qur'ans reader is addressed: Read and get promoted. Recite the way you used to in your life: your ranking position is with your last verse you read" (Al Tirmithi, Reward of the Qur'an: no 2915).

Our Messenger praised a group of his noble companions for their precise recitation and tajweed of the Qur'an as perfectly as it should be. They became glorious celebrities. Examples of these are; Ubai bin Ka'b, Abdullah bin Mas'oud, Zaid bin Thabit, and many others of the Prophet's companions: the Prophet used to recite the Qur'an to them, and listen to them reading It. (Nassre, 1994).

Reading the Qur'an is not like reading other books. It needs a set of conventions and special rules to read so precisely correctly void of any errors. Of these conventions is pronouncing the sounds through the correct track; in addition to the long vowels and other morphological rules, and rules related to where to stopping and where to restart: that is tajweed, mastering of its rules regulates and gives good command of the Qur'anic reading (Al Fooli, 2008). 
Tajweed as a science has got certain speciality. That is, in order to master it one needs competence of the two-fold sides: the theoretical framework where the subject is explained, as well as the empirical side where application is practiced. The later side in particular needs kind of verbal inculcating by a teacher's directly (Atta', 2009).

For teaching and learning the Qur'an there is a set of moral conventions a teacher and learner must commit themselves to and observe very carefully. On top of those Holy Qur'an's teacher morals is intention of loyalty to Allah (Most High) in this job. He/she also should possess high morals; choose the best of teaching methods compatibly with what suits the students; use the most updated educational technology in order to assist the learners to improve and master recitation and tajweed skills; and observe individual differences among the students. As for the learner, he should concentrate well at the recitation and tajweed class sensing the Great Book he is learning (as Allah is speaking to him), (Abu Mousa, 2011).

\section{Literature review}

Having particular significance, the issue of recitation and tajweed was subject to many research studies aiming at improving these skills in many ways.Khan (2013) aims at exploring common errors third secondary students at public education make in reciting and tajweeding the Holy Qur'an. The study used descriptive research methodology, explored a set of common errors, and suggested remedial action for these errors. Findings of this study revealed that a remedial programme is possible (the study suggests) by cooperation of all parties: family, student, teacher, educational institutes (schools), and education supervision.

Al Raqb (2009) experimented effectiveness of a computer programme in developing the recitation skills within the eleventh graders. The researcher used the constructivist paradigm/experimental methodology. He selected a sample of (\# 60) eleventh grade students affiliating to Khalid Al Hassan secondary school. Then, a purposive sample (\# 28) students was assigned as experimental group; and (\# 32) students were assigned as a comparison group. Results of this study revealed that there was a statistically significant difference in the achievement tests and practical performance in favour of the experimental group.

Al Shummari (2007) aimed at acquainting Ha'el Teachers' College students some Qur'anic recitation skills through a language laboratory-based programme. The researcher selected a sample of (\# 50) students distributed equally into two groups: a comparison and an experimental group. The vital finding this study revealed was that the experimental group surpassed the comparison group.

In the Saudi Saudi Aal Dawood (2005) prepared a programme to remedy sixth grade pupils' weakness in Qur'an Recitation. He experimented effectiveness of this on the pupils performance in this subject. The researcher selected a sample (\# 60) of the sixth grade distributed equally into two groups: one comparison group and one experimental. The experiment revealed outstanding performance of the experimental group over the control group in the Qur'anic recitation.

Mattar's (2004) study aimed at exploring the effect of multi-methods on developing tajweed skills within the Qur'anic Centre of the Islamic University in Ghazza, Palistine. A sample of 
(\# 60) students were assigned into three groups: one group studied with the multi-method style, a second with the video assistance (both considered as experimental groups), and a third (a comparison group) studied normally with traditionally method. The results revealed overachievement of the two experimental groups over the comparison group. The multi-method group achieved best.

In the same vein, Mustafa (1999) experimented the impact of the computer-assisted Qur'anic recitation on Jordanian students mastering of recitation and tajweed skills. The samples constituted a comparison group of (\# 32) male plus (\#35) female students (a total of 67 students); and an experimental group of (\#33) male plus (\#25) female students (a total of $\mathbf{5 8}$ students). The experimental group surpassed the comparison group.

This review of related literature indicates that the current study agrees with (a body of) previous studies in terms of the aims: i.e. improving student recitation and tajweed skills. However, it distinguishably differs from them in terms of the data instrument used: teacher-as-informants through questionnaires; detecting teachers' points of view on how to improve school students' recitation and tajweed.

\section{The research problem}

Recitation and tajweed (the Qur'an) is one of the skills that students in the Arab/Muslim context should master, as it is connected with a religious duty: reading the Qur'an (accurately correctly).

A bulk of studies tackled weakness of the students' recitation and tajweed skills. Al Zu'bi (2013) for example indicated students Qur'anic recitation and tajweed performance weakness. This was also asserted by Al Zagghat (2005); and is in line with Abu Mousa (2011), Al Mu'ajjil (2001). Accordingly, the author of this study realized the importance conducting exploratory research tackling ways of improving Qur'anic recitation and tajweed in the Islamic education teachers' viewpoint.

\section{The research questions}

This study attempts to answer the following question:

First question: what are the improvement strategies for students' recitation and tajweed skills in the viewpoint of the Islamic education teachers in the governorate of Tafilah?

Second question: are there any differences in the improvement strategies for students' recitation and tajweed skills that can be attributed to the variables of 'gender' or 'teaching experience'?

\section{Research objectives}

This study aims to explore point of view of the Islamic Education teachers in Tafilah governorate about strategies of improving students' Qur'anic recitation and tajweed skills. 


\section{Significance of the study}

Importance of the study lies in detecting the most important strategies to be used for improving students' recitation and tajweed of the Qur'an in the viewpoint of the Islamic Education teachers as specialists in the field. To the researcher's knowledge, it is the first study of its kind: detecting and depicting male and female Islamic Education teachers' points of view on most important strategies for improving recitation and tajweed skills.

\section{Scope of the study}

- Time scope: the study was conducted in, and results are restricted to the second term of the academic year 2016 / 2017.

- Place scope: Al Tafilah governorate.

- Context scope: (male and female) Islamic Education teachers

- Subject scope: Qur'anic recitation and tajweed skills.

\section{Definition of terms}

First, strategies: are a set of processes and steps shared among all four partners of the educational process: the teacher, learner, Recitation \& Tajweed course, and the Ministry of Education; all aiming at improving recitation and tajweed skills within the students; these processes and steps are described into four sections in the data collection instrument: the questionnaire.

Second, recitation and tajweed skills: are a collection of rules concerned in how to read the Holy Qur'an so correctly as to observe all phonetic/phonemic and morphological rules regarding the Qur'an's phonemes and sounds.

Third, Tafilah governorate: is one of the administrative districts of the Hashemite Kingdom of Jordan, around $200 \mathrm{~km}$ south of the capital Amman, Jordan.

Fourth, Islamic Education teachers: all Islamic Education teachers, male or female, all over Al Tafilah schools.

\section{The research methodology}

This study used the descriptive research methodology, and employed a questionnaire as data collection instrument; as this is seen most appropriate to achieve the research objectives.

\section{Method and procedures}

In this section the study target population and sample are described. Additionally, data collection instrument and how it has been established, and the type of statistical data analysis are nuanced.

- Population of the study: this constitutes all (\# 217) male and female Islamic Education teachers in Tafilah for the academic year 2016/2017. Twenty of these were chosen for 


\section{Macrothink}

Journal of Studies in Education

ISSN 2162-6952

2017, Vol. 7, No. 4

reliability tests of the instrument and the remaining (\# 197) were the subjects (sample) to whom the study was applied.

- Sample of the study: is identical with the target population. Table (1) shows distribution of the sample in terms of the 'gender' and 'teaching experience'.

- Data collection instrument: is composed of four major sections of 30 items. The instrument was built on basis of the following:

- Reviewing previous literature in relation with the current study's issue to elicit major items of the instrument.

- Building up primitive version of questionnaire.

Table 1. Description of the Sample in terms of gender and teaching experience

\begin{tabular}{|c|c|c|}
\hline Gender & Frequency & Percentage \\
\hline Male & 82 & 41.6 \\
\hline Female & 115 & 58.4 \\
\hline Total & 197 & 100 \\
\hline Teaching Experience & & \\
\hline Less than ten yrs & 98 & 49.7 \\
\hline More than ten yrs & 99 & 50.3 \\
\hline Total & 197 & 100 \\
\hline
\end{tabular}

- Handing out the instrument to a jury of experts for content validity.

- Making modifications in the light of the jury's comments until it took its final version. A 5-point Likert-type scale was used for the participants responses: that is [strongly agree (5 marks value), agree (4 marks), neutral (3 marks), disagree (2 marks), strongly disagree (1 mark)].

- The instrument was distributed to twenty teachers of the target population (and outside the target population) to ascertain instrument reliability.

- Final version of the instrument was distributed to the participants (teachers of Islamic Education),

- Collecting completed questionnaires from the participants.

- Data analysis using the SPSS. 


\section{Macrothink}

Instrument reliability: after distributing the instrument to the population sample (\# 20 students) and to a sample outside the population, Alpha Cronbach's correlation co-efficient was used to test reliability as stability. Table (2) shows the test result.

As shown in the table overall reliability coefficient was $(r=0.924)$. The calculated value indicated a highly positive correlation in Hinkle's et. al. (2003) classification between recurrences of the one test: hence, reliability of the instruments.

Descriptive statistics used: (SPSS) Averages, Means, St Ds, and ranking were used to answer the first; and Two-way- ANOVA was used to answer the second question.

Table 2. Alpha Cronbach's correlation co-efficient test result

\begin{tabular}{|l|c|}
\hline \multicolumn{1}{|c|}{$\begin{array}{c}\text { Questionnaire } \\
\text { Section }\end{array}$} & $\begin{array}{c}\text { Reliability } \\
\text { Co-efficient }\end{array}$ \\
\hline $1^{\text {st }}$ section & .795 \\
\hline $2^{\text {nd }}$ section & .781 \\
\hline $3^{\text {rd }}$ section & .811 \\
\hline $4^{\text {th }}$ section & .908 \\
\hline Overall Co-efficient of the instrument & .924 \\
\hline
\end{tabular}

\section{Findings of the study and discussion}

To answer the first question, reading: what are the improvement strategies for students' recitation and tajweed skills in the viewpoint of the Islamic education teachers in the governorate of Tafilah?, Means, St Ds, and Ranking of the questionnaire items. Table (3) shows the result of these.

The table below shows the Means and St Ds and ranking of the Islamic Education teachers' responses to the questionnaire's items. Ranking order of the items according to their means was as follows: 
Table 3. Means and St Ds of the (male and female) Islamic Education teachers' responses

\begin{tabular}{|c|c|c|c|c|}
\hline \multicolumn{2}{|r|}{$\begin{array}{c}\text { Section 1: Strategic items/processes in relation with } \\
\text { Islamic Education Teachers }\end{array}$} & Mean & $\begin{array}{c}\mathrm{St} \\
\text { Deviation }\end{array}$ & Rank \\
\hline 1 & Tasking recitation and tajweed to a professional teacher & 4.76 & .552 & 3 \\
\hline 2 & $\begin{array}{l}\text { Students' suspense for the Recitation \& Tajweed class in } \\
\text { different ways }\end{array}$ & 4.62 & .563 & 6 \\
\hline 3 & $\begin{array}{l}\text { Employment of modern educational technology into } \\
\text { Recitation \& Tajweed }\end{array}$ & 4.52 & .635 & 13 \\
\hline 4 & $\begin{array}{l}\text { Utilising teaching methods that focus on the practical side of } \\
\text { Recitation \& Tajweed classes }\end{array}$ & 4.84 & 3.63 & 1 \\
\hline 5 & $\begin{array}{l}\text { Variety of teaching methods of Recitation \& Tajweed, in order } \\
\text { to observe individual differences among the students in } \\
\text { acquiring the Recitation \& Tajweed skills }\end{array}$ & 4.55 & .592 & 11 \\
\hline 6 & $\begin{array}{l}\text { Reviewing Recitation \& Tajweed assessment criteria as to } \\
\text { focus more on the practical than on the theoretical side of the } \\
\text { subject }\end{array}$ & 4.71 & 3.67 & 4 \\
\hline 7 & $\begin{array}{l}\text { Co-operation with students' parents for improving students' } \\
\text { level of Recitation \& Tajweed }\end{array}$ & 4.46 & .576 & 19 \\
\hline 8 & $\begin{array}{l}\text { Reinforcing innocent competitive atmosphere among the } \\
\text { students to master Recitation \& Tajweed skills }\end{array}$ & 4.49 & 659 & 17 \\
\hline 9 & $\begin{array}{l}\text { Encouraging students master Recitation \& Tajweed through } \\
\text { continual reinforcement }\end{array}$ & 4.56 & .664 & 9 \\
\hline 10 & $\begin{array}{l}\text { Assign students homework assignments related to recitation \& } \\
\text { Tajweed }\end{array}$ & 4.37 & .814 & 25 \\
\hline \multicolumn{2}{|r|}{ Section 2: Strategic items/processes in relation with the students } & & & \\
\hline 1 & $\begin{array}{l}\text { Student's preparation of the Recitation \& Tajweed subject } \\
\text { matter (prior to class) }\end{array}$ & 4.46 & .688 & 20 \\
\hline 2 & $\begin{array}{l}\text { Students' follow up, of their concentration in Recitation \& } \\
\text { Tajweed class in particular }\end{array}$ & 4.55 & .608 & 10 \\
\hline 3 & $\begin{array}{l}\text { Students' daily follow up of their Recitation \& Tajweed } \\
\text { lessons at home }\end{array}$ & 4.49 & .667 & 16 \\
\hline 4 & $\begin{array}{l}\text { Students' following of the websites specialized in Recitation } \\
\text { \& Tajweed applications }\end{array}$ & 4.18 & .827 & 28 \\
\hline 5 & $\begin{array}{l}\text { Relying on more than one source for mastering Recitation \& } \\
\text { Tajweed; non dependence on the mono-source : the teacher } \\
\text { alone }\end{array}$ & 4.28 & .828 & 27 \\
\hline \multicolumn{2}{|r|}{$\begin{array}{c}\text { Section 3: Strategic items/processes in relation with } \\
\text { Recitation \& Tajweed course }\end{array}$} & & & \\
\hline 1 & $\begin{array}{l}\text { Re-designing/editing the Recitation \& Tajweed book } \\
\text { technically well as to prompt students to read it }\end{array}$ & 4.28 & .910 & 27 \\
\hline
\end{tabular}




\begin{tabular}{|c|c|c|c|c|}
\hline 2 & $\begin{array}{l}\text { Re-arranging the Recitation \& Tajweed course book content, } \\
\text { as to expand while progressing compatibly with the level stage } \\
\text { (vertically) }\end{array}$ & 4.44 & 2.95 & 21 \\
\hline 3 & $\begin{array}{l}\text { Focusing on quality rather than quantity while introducing the } \\
\text { subject matters }\end{array}$ & 4.57 & 3.68 & 8 \\
\hline 4 & Content emphasis on continual self- assessment & 4.48 & 3.70 & 18 \\
\hline 5 & $\begin{array}{l}\text { Increasing number of examples on each of the Recitation \& } \\
\text { Tajweed course skills }\end{array}$ & 4.42 & .663 & 22 \\
\hline 6 & $\begin{array}{l}\text { Supporting the book with illustrations and coloured words that } \\
\text { clarify Recitation \& Tajweed rules }\end{array}$ & 4.50 & .799 & 15 \\
\hline 7 & $\begin{array}{l}\text { Supplementing Recitation \& Tajweed course with ready-made } \\
\text { applications exercises as software (CDs) }\end{array}$ & 4.68 & 3.68 & 5 \\
\hline \multicolumn{2}{|r|}{$\begin{array}{c}\text { Section 4: Strategic items/processes in relation with the } \\
\text { Ministry of Education }\end{array}$} & & & \\
\hline 1 & Increasing number of Recitation \& Tajweed classes & 4.30 & 1.00 & 26 \\
\hline 2 & $\begin{array}{l}\text { Arranging competitions among students (at the Districts level) } \\
\text { in the Recitation \& Tajweed skills }\end{array}$ & 4.45 & .785 & 20 \\
\hline 3 & $\begin{array}{l}\text { Budgeting bonus or providing moral promotions to students } \\
\text { showing good Recitation \& Tajweed performance }\end{array}$ & 4.80 & 3.66 & 2 \\
\hline 4 & $\begin{array}{l}\text { Deciding mastering Recitation \& Tajweed skills existing in the } \\
\text { course book as a criterion for an Islamic Education teacher's } \\
\text { promotion }\end{array}$ & 4.37 & .833 & 26 \\
\hline 5 & $\begin{array}{l}\text { Teaching Recitation \& Tajweed course as of first basic classes } \\
\text { up to the secondary stage }\end{array}$ & 4.41 & .885 & 23 \\
\hline 6 & $\begin{array}{l}\text { Including Recitation \& Tajweed course as a subject within the } \\
\text { General Secondary Certificate exams }\end{array}$ & 4.32 & .825 & 25 \\
\hline 7 & $\begin{array}{l}\text { Arranging courses in Recitation \& Tajweed for Islamic } \\
\text { Education teachers periodically }\end{array}$ & 4.45 & .702 & 20 \\
\hline 8 & $\begin{array}{l}\text { Continual follow up for Islamic Education teachers over } \\
\text { Recitation \& Tajweed skills through supervisory visits }\end{array}$ & 4.61 & 3.691 & 7 \\
\hline 9 & $\begin{array}{l}\text { Prompting excellent Recitation \& Tajweed skills performers } \\
\text { materially and morally }\end{array}$ & 4.54 & .665 & 12 \\
\hline 10 & $\begin{array}{l}\text { Providing teachers with educational bulletin specially } \\
\text { concerned in Recitation \& Tajweed skills and its teaching } \\
\text { methods }\end{array}$ & 4.54 & .695 & 13 \\
\hline
\end{tabular}

'Utilising teaching methods that focus on the practical side of Recitation \& Tajweed classes', an item within the 'Teachers' section, was ranked on top (no. 1); with a mean of (4.8426). This denotes the great responsibility placed on the Islamic Education teacher as to choose teaching methods that focus on the practical side more than on the theoretical teaching of Recitation \& Tajweed; because mastering Recitation \& Tajweed skills is more closely correlated with the practical side than with the theoretical stuff. 
'Budgeting bonus or providing moral promotions to students showing good Recitation \& Tajweed performance', an item affiliating to the Ministry of Education's processes, came in the second position: ranked no.(2); with a Mean of (4.8071). This denotes the importance of motivation and reinforcement principles which functions as to prompt students to endeavour until they reach the mastery level of the 'skill of recitation and tajweed'. This is responsibility of the Ministry of Education budgeting financial amounts rewarding outstanding students in the field, and encouraging others to do the same.

'Tasking recitation and tajweed to a professional teacher', within the 'Teacher' domain, was ranked no. (3), with a Mean of (4.7614). This highlights the necessity for such a module's teacher to have professional mastery of the skills in relation: a person void of knowledge and skillfulness of something cannot give (to his students) the things they need in such domain. Moreover, a professional teacher is a leading example for the student: this strengthens student-teacher trustworthiness.

'Reviewing Recitation \& Tajweed assessment criteria as to focus more on the practical than on the theoretical side of the subject', a process within the 'Teacher' domain took the $4^{\text {th }}$ rank; with a Mean of (4.7157). This asserts the tendency for focusing on the practical side as to even include the subject's evaluation and assessment; integrally with teaching methods which emphasizes the practical aspects of reciting and tajweed. Evaluation and assessment is a station in the teaching-learning process that acknowledges student's areas of weakness, so that he/she endeavours to avoid (gradually) until he reaches the mastery level.

The $5^{\text {th }}$ rank was an item in the Recitation \& Tajweed course domain: that is 'Supplementing Recitation \& Tajweed course with ready-made applications exercises as software (CDs)'; with a Mean (4.6853). This facility is a service available to the student any time anywhere; and allows repetition of the exercises (so many times). In addition, it constitutes a source of attraction to the students; the fact that contributes in the students' motivation to learn Quranic recitation and tajweed.

The $6^{\text {th }}$ rank was 'Students' suspense for the Recitation \& Tajweed class in different ways', also of the 'Teacher' domain; with a Mean of (4.6244). Students evoking with the various Islamic Education subject matters, in general; and with the recitation issues, in particular, definitely evokes their desire to learn Recitation \&Tajweed. Consequently, this enhances students level of concentration on the Recitation \& Tajweed lessons; the fact that facilitates its mastery.

Rank no. (7) was 'Continual follow up for Islamic Education teachers over Recitation \& Tajweed skills through supervisory visits', of the Ministry of Education domain; with a Mean of (4.6142). Continual follow up for the Islamic Education teachers contributes effectively to improving their Recitation \& Tajweed skills; which reflect positively on the students' development of these skills.

No. (8) was 'Focusing on quality rather than quantity while introducing the subject matters', affiliating to the Recitation \& Tajweed course domain; with a Mean of (4.5736). Stuffing the Recitation \& Tajweed course with many subject matters will impact negatively on 
Recitation \& Tajweed skills learning. That is, full acquisition of such skills demands a span of time. Teaching session are time-limited. Thus, a student's mastery of some of the domain's skills is much better than studying a large group of such Recitation \& Tajweed issues/skills with lower level of accuracy.

To answer the second question, reading: are there any differences in the improvement strategies for students' recitation and tajweed skills that can be attributed to the variables of gender or teaching experience?, Two-way ANOVA analysis was used. Results of this are shown in table (4).

Table 4. The Two-way ANOVA analysis Results

\begin{tabular}{|c|c|c|c|c|c|}
\hline Source & $\begin{array}{c}\text { Type III Sum } \\
\text { of Squares }\end{array}$ & Df & Mean Square & F & Sig. \\
\hline Model & $4.008 \mathrm{E6}^{\mathrm{a}}$ & 4 & 1002037.326 & $4.317 \mathrm{E} 3$ & .000 \\
Gender & 388.416 & 1 & 388.416 & 1.674 & .197 \\
Experience & 69.954 & 1 & 69.954 & .301 & .584 \\
Gender * Experience & 56.951 & 1 & 56.951 & .245 & .621 \\
Error & 44329.694 & 191 & 232.093 & & \\
Total & 4052479.000 & 195 & & & \\
\hline
\end{tabular}

Table 4 indicates that the there is no statistically significant difference at $(\alpha=0.05)$ level that can be attributed to the 'gender variable' (male or female teachers): sig. (.197).

The Table also indicates that the there is no statistically significant difference at $(\alpha=0.05)$ level that can be attributed to the 'teaching experience variable': sig. (.584).

The table also indicates that the there is no statistically significant difference at $(\alpha=0.05)$ level between 'gender' and the 'teaching experience': sig. (.621).

As a general conclusion there exist common context-wide thoughts teachers share about the importance of taking the strategies described in the questionnaire (represented in its items), regardless of their gender. All agree that these are necessary for the Recitation \& Tajweed students' acquisition mastery of the subject.

\section{Recommendations}

In the light of the findings, the study recommends:

1. Emphasis that Islamic Education teachers master the Recitation and Tajweed skills as a necessity before they are tasked this job. 
2. Emphasis on utilizing educational technology in Recitation and Tajweed lessons.

3. Developing Recitation and Tajweed course curriculum as to present appropriate subject matters in terms of quality and quantity.

4. Conducting further experimental and theoretical studies that contribute to the students' accuracy and mastery of recitation and tajweed.

\section{References}

Aal Dawood, I. M. (1427). The impact of a suggested remedial programme to treat sith graders' weakness in Recitation and Tajweed. Unpublished master's dissertation, Islamic University of Immam Muhammd Bin Saoud, KSA.

Abdul Hameed, S. (2001). Tayseer Al Rahman in Reciting the Qur'an. (4 ${ }^{\text {th }}$ ed). Dar al Taqwa for Pub. And Dist., Cairo, Egypt.

Abu Mousa, F. H. (2011). Precision level of the Qur'anic recitation and tajweed skills within basic $10^{\text {th }}$ grade and its correlation with their tendencies towards these skills. Un published master's dissertation. Islamic University, Ghazza, Palestine.

Al Daghameen, Z. (1999). The Holy Qur'an Between Horizons of Recitation and Tajweed. Islamic Sharee'ah Journal, 37, 15-61. Council for Scientific Publication, University of Kuwait.

Al Fooli, M. A. (1988). The Holy Qur'an Teacher's Book for the Basic Education Stage in the Arab Word. Arab Organisation for Education, Culture and Sciences, Tunisia.

Al Jamal, A. Y. (2004). Sufficiently Rich Book in Tajweed Rules (4 ${ }^{\text {th }}$ ed). Afaq Library, Gazzah.

Al Raqb, A. M. (2009). Effectiveness of a computer-assisted programme for developing recitation skills of the $11^{\text {th }}$ grade students. Unpublished master's degree dissertation. Islamic University, Ghazza, Palestine.

Al Shummary, S. M. (1427 H). The impact of using the language lab for teaching the Holy Qur'an on Ha'el Teachers College students' acquisition of some recitation skills. Unpublished master's dissertation. Faculty of Education, Ummul Qura University, KSA.

Atta', I. M. (2009). The Reference in Islamic Education. Al Kitab Centre for Pub., Cairo. Egypt.

Hinkle et. al. (2003). Applied Statistics for the Behavioral Sciences. (5 $5^{\text {th }}$ edition). Boston, Mass. Houghton Mifflin ; [London : Hi Marketing for Dist.]

Jum'ah, I. A. (2004). Easy Rules for Recitation and Tajweed. (1 ${ }^{\text {st }}$ ed). Dar Al Nafa'es for Pub. and Dist., Jordan.

Khan, A. A. (2013). Common errors in reciting and tajweeding the Qur'an within $3^{\text {rd }}$ secondary students in Holy Makka, and ways of remedying them. Unpublished master's dissertation. Ummul Qura University. KSA. 


\section{Macrothink}

Journal of Studies in Education

ISSN 2162-6952 2017, Vol. 7, No. 4

Mattar, Y. (2004). Impact of a multi-method programme on developing tajweed skill of The Holyt Qur'an Centre students. Unpublished master's degree dissertation, Islamic University, Ghazza, Palestine.

Mustafa, Z. A. (1999). The impact of the computer on precision of recitation and tajweed rules. Unpublished master's degree dissertation, Aal Al Bait University, Jordan.

Nassre, A. Q. (1994). The Learner's Utmost Purpose in Tajweed Science. (4 ${ }^{\text {th }}$ ed). General Administration for Publications, Riyadh, KSA.

Ramadan, M. M. (1425). Concept of reading, recitation, and comprehension contemplation of the Qur'anic verses. Ummul Qura University Journal, 18(3), 63-115. 